Received: 2019/01/10, Revised: 2019/03/07, Accepted: 2019/03/19, Published: 2019/03/31 (2019 Jae Ho Park et al.; License Joumal of Exercise Nutrition and Biochemistry. This is an open access article distributed under the terms of the creative commons altribution license (http://creativecommons.orglicenses/by/2.0), which permits unrestricted use, distribution, and reproduction in any medium, provided the orginal work is properly cited. ${ }^{*}$ Corresponding author : Sok Park

Institute of Sports Medicine \& Nutrition, Kwangwoon University, Seoul, Republic of Korea

Phone: +82-2-940-8321

E-mail: winner@kw.ac.kr

@2019 The Korean Society for Exercise Nutrition

\section{Effects of aerobic exercise training on the risk factors for liver diseases in elderly women with obesity and impaired fasting glucose: A pilot study}

\author{
Jae Ho Park ${ }^{1}$ / Hee-jae Kim² / Aleum Han ${ }^{3}$ / Deuk-mo Kang ${ }^{3}$ /
} Sok Park ${ }^{1^{*}}$

1. Institute of Sports Medicine \& Nutrition, Kwangwoon University, Seoul, Republic of Korea

2. Institute of Sports Science, Seoul National University, Seoul, Republic of Korea

3. Department of Physical Education, Sejong University, Seoul, Republic of Korea
[Purpose] In the present pilot study, we aimed to investigate the effects of the Silverrobics exercise program, which is similar to aerobic dance, on the factors related to glucose metabolism and liver enzymes.

[Methods] Eight elderly women with obesity and impaired fasting glucose participated in the Silverrobics exercise program (60 minutes per session for five times a week for 8 weeks). The program was conducted at $50-60 \%$ of the heart rate reserve at 1 to 2 weeks and at $60-80 \%$ of the heart rate reserve at 3 to 8 weeks. To verify the effect of this 8-week exercise program on glucose metabolism and liver enzymes, blood analysis at pre- and post-training was performed.

[Results] After the Silverrobics exercise program, there were significant decreases in the glucose $(p<0.05)$, glycated hemoglobin A1c $(\mathrm{p}<0.05), 1,5$-anhydroglucitol $(p<0.05)$, and insulin levels $(p<0.01)$ and homeostatic model assessment of insulin resistance score $(p<0.05)$. However, there were no significant effects on the liver enzymes, except for alkaline phosphatase. The alkaline phosphatase level increased after the Silverrobics exercise program $(p<0.05)$.

[Conclusion] Although the Silverrobics exercise program had no beneficial effects on the liver enzymes, it may play an important role in preventing liver diseases considering the effects on glucose metabolism.

[Key words] Obesity, Impaired fasting glucose, Liver disease, Aerobic exercise

\section{INTRODUCTION}

Obesity has become a global public health problem. According to the World Health Organization, approximately 39\% of adults are overweight, and $13 \%$ are obese ${ }^{1}$. Although there is a great global obesity pandemic, the prevalence of obesity is greater in women than in men in most populations ${ }^{2-5}$. There is accumulating evidence that the prevalence of sarcopenic obesity in elderly women is higher than that in elderly men; thus, early management of body composition with adequate lifestyle changes is more important for women than for men ${ }^{6}$. Epidemiological evidence suggests that menopausal transition is an important factor for increasing body weight and fat mass ${ }^{7}$.

Liver diseases, such as nonalcoholic fatty liver disease (NAFLD), are strongly related to obesity $8-11$. Although only $18 \%$ of individuals with a normal body mass index (BMI) are patients with NAFLD, up to $70 \%$ of patients with NAFLD are obes ${ }^{12}$. The resulting obesity epidemic has made liver diseases, such as NAFLD, become one of the common diseases worldwide ${ }^{13,14}$. NAFLD should be prevented because it can progress to nonalcoholic steatohepatitis (NASH), which can consequently increase the risk of cirrhosis or even hepatocellular carcinoma (HCC $)^{15,16}$. NAFLD is marked by upregulated liver enzymes, such as aspartate aminotransferase (AST) and alanine aminotransferase $(\mathrm{ALT})^{17}$. Further, there are other enzymes related to liver damage and function, such as alkaline phosphatase (ALP) and albumin ${ }^{18}$. Moreover, the AST/ALT ratio is a critical risk factor for predicting liver damage because the levels of AST increase more than those of ALT when hepatocellular death increases ${ }^{19}$.

Obesity is also one of the major causes of insulin resistance (IR). Several inflammatory cytokines from fat tissues have been suggested as a major factor inducing IR. Inflammatory cytokines, such as tumor necrosis factor- $\alpha$ and interleukin- 6 , cause IR; thus, overexpression of these cytokines increases the prevalence of type 2 diabetes and metabolic syndrome ${ }^{20,21}$. Importantly, IR and obesity have been identified as critical risk factors for liver diseases, such as NAFLD and 
even $\mathrm{HCC}^{22,23}$. Further, impairment of the hepatic insulin signaling pathway is closely related to an increment in hepatocyte apoptosis in patients with liver diseases ${ }^{24}$. Moreover, high levels of glucose [i.e., impaired fasting glucose (IFG)] are closely associated with hepatic fat and hepatocyte apoptosis ${ }^{25,26}$. Therefore, it could be concluded that impaired glucose metabolism in obesity has clinical implications for liver diseases.

Exercise has been proven to be a good strategy for treating obesity and IFG. Considering the relationship between obesity and liver diseases explained above, it is likely that exercise could have beneficial effects on liver diseases. Exercise has been reported to affect NAFLD treatment positively via improvement of insulin sensitivity and reduction of body weight ${ }^{27}$. However, the role of exercise in treating NAFLD has not been completely identified, and what exercise regimen is the most beneficial for liver diseases is unknown ${ }^{14,28}$. A few studies have investigated the effect of exercise on both glucose metabolism and liver enzymes. A previous study reported significant reductions in the AST and ALT levels, as well as the value of IR, in Iranian men (age, 32-54 years) with NAFLD who adhered to an 8-week aerobic exercise or resistance exercise program ${ }^{28}$. These results demonstrate that both aerobic exercise and resistance exercise can alleviate the risk factors of liver diseases. There were also significant decreases in the AST and ALT levels in women with obesity (age, 18-65 years) who engaged in a 3-month aerobic exercise with resistance exercise ${ }^{29}$. These results showed that exercise can have beneficial effects on the risk factors of liver diseases in adult women (age, $<65$ years). However, the previous authors could not assess factors related to glucose metabolism. Considering the value of the IR as a risk factor of liver diseases, further studies are required for verification. To the best of our knowledge, there are no data on the effects of aerobic exercise on both liver enzymes and glucose metabolism in elderly Korean women with obesity and IFG. Therefore, this study was conducted.

The purpose of this pilot study was to investigate whether regular aerobic exercises in elderly women with obesity and IFG have beneficial effects on both glucose metabolism and liver enzymes. We expect the preliminary results to offer relevant information for designing further studies and facilitating planning of the exercise program and management of participants. To verify this, we hypothesized that regular aerobic exercises in elderly women with obesity and IFG could enhance glucose metabolism, resulting in the reduction of the risk factors for liver diseases.

\section{METHODS}

\section{Participants}

Participants were openly recruited through advertising in the community and personal contact. We sought elderly women aged 65 to 70 years with obesity and IFG who had no medical history that could prevent them from attending an 8-week exercise program. The exclusion criteria included current usage of medications that can affect glucose metabolism and liver enzymes. According to the American Diabetes Association, IFG was defined as fasting glucose levels between 100 and $125 \mathrm{mg} / \mathrm{dL}^{30}$. Obesity was defined in accordance with the criteria used in the Asian and Pacific regions (BMI, $\left.\geq 25 \mathrm{~kg} / \mathrm{m}^{2}\right)^{31}$. All volunteers had obesity and IFG. All participants provided written informed consent after explanation of the study and possible adverse effects. The anthropometric characteristics of the participants are shown in Table 2 .

\section{Procedures}

Approximately 2 weeks prior to the baseline measurements, the participants visited the laboratory for familiarization with the pre-test. They were required to avoid performing any vigorous physical activity, drinking, and smoking 24 hours prior to the study. Further, the participants were recommended to get enough sleep. To verify the effect of the 8-week exercise on glucose metabolism and liver enzymes, blood analysis at pre- and post-training was performed. The participants underwent aerobic exercise training during the 8 -week intervention period.

\section{Aerobic exercise training}

All participants started the aerobic exercise following the baseline measurements. The aerobic exercise program used in this study was the Silverrobics exercise program (SEP), which is similar to aerobic dance. The SEP is a modified form of aerobic dance for elderly individuals. During the 8-week training period, all subjects participated in the SEP for 60 minutes per session (including warm-up and cool-down) five times a week under the instruction of an SEP expert and supervision of an exercise physiologist. The SEP consists of three phases: (1) warm-up, (2) main exercise, and (3) cool-down. At the beginning of the SEP session, the participants conducted 10 minutes of warmup, including stand stretch and rhythmic step stretch. The warm-up was followed by the main exercise. The main exercise of the SEP consists of aerobic dance performed on music for 30 to 40 minutes. This phase was conducted at $50-60 \%$ of the heart rate reserve (HRR) and at $10-12$ of the rating of perceived exertion (RPE; Borg scale) at 1 to 2 weeks. Thereafter, the intensity was progressively increased at $60-80 \%$ of the HRR and $10-16$ of the RPE at 3 to 8 weeks. The target heart rate (THR) was calculated using the following formula: [THR $=($ maximal heart rate - resting heart rate $) \times$ target intensity $(\%)+$ resting heart rate]. The maximal heart rate was calculated using the following formula: (maximal heart rate $=220-$ age) . To measure the THR, each participant underwent heart rate monitoring using a polar heart rate monitor (Polar, Finland). Lastly, the participants performed cool-down, including light resistance exercise using a dumbbell or an elastic band and supine stretch, to allow their heart rate to drop slowly. The details of the SEP are shown in Table 1. 
Table 1. Silverrobics exercise program

\begin{tabular}{|c|c|c|c|c|c|c|c|c|}
\hline \multirow{2}{*}{\multicolumn{2}{|c|}{ Phase }} & \multirow{2}{*}{$\begin{array}{c}\text { Exercise } \\
\text { mode } \\
(\mathrm{HR})\end{array}$} & \multicolumn{6}{|c|}{ Exercise periods } \\
\hline & & & $\begin{array}{c}1-2 \\
\text { weeks }\end{array}$ & Intensity & $\begin{array}{c}\text { 3-5 } \\
\text { weeks }\end{array}$ & Intensity & $\begin{array}{c}6-8 \\
\text { weeks }\end{array}$ & Intensity \\
\hline \multirow{2}{*}{ Warm- up } & Warm-up & $\begin{array}{c}\text { Stand } \\
\text { Stretch } \\
(110-120)\end{array}$ & $\begin{array}{c}5 \\
\min \end{array}$ & $\begin{array}{l}\text { HRR } \\
50 \% \\
-60 \%\end{array}$ & $\begin{array}{c}5 \\
\min \end{array}$ & $\begin{array}{l}\text { HRR } \\
50 \% \\
-60 \%\end{array}$ & $\begin{array}{c}5 \\
\min \end{array}$ & $\begin{array}{l}\text { HRR } \\
50 \% \\
-60 \%\end{array}$ \\
\hline & $\begin{array}{c}\text { Hi- } \\
\text { Warm-up }\end{array}$ & $\begin{array}{c}\text { Step } \\
\text { Stretch } \\
(120-130)\end{array}$ & $\begin{array}{c}5 \\
\min \end{array}$ & $\begin{array}{l}\text { HRR } \\
50 \% \\
-60 \%\end{array}$ & $\begin{array}{c}5 \\
\min \end{array}$ & $\begin{array}{l}\text { HRR } \\
60 \% \\
-70 \%\end{array}$ & $\begin{array}{c}5 \\
\min \end{array}$ & $\begin{array}{l}\text { HRR } \\
60 \% \\
-70 \% \\
\end{array}$ \\
\hline \multirow{2}{*}{\multicolumn{2}{|c|}{ Main exercise }} & $\begin{array}{c}\text { Aerobic } \\
\text { dance } \\
(120-140) \\
\end{array}$ & $\begin{array}{l}20 \\
\min \end{array}$ & $\begin{array}{l}\text { HRR } \\
50 \% \\
-60 \% \\
\end{array}$ & $\begin{array}{l}20 \\
\min \end{array}$ & $\begin{array}{l}\text { HRR } \\
60 \% \\
-80 \% \\
\end{array}$ & $\begin{array}{l}20 \\
\min \end{array}$ & $\begin{array}{l}\text { HRR } \\
60 \% \\
-80 \% \\
\end{array}$ \\
\hline & & $\begin{array}{c}\text { Aerobic } \\
\text { step } \\
(120-130)\end{array}$ & $\begin{array}{l}20 \\
\min \end{array}$ & $\begin{array}{l}\text { HRR } \\
50 \% \\
-60 \%\end{array}$ & $\begin{array}{l}20 \\
\min \end{array}$ & $\begin{array}{l}\text { HRR } \\
50 \% \\
-60 \%\end{array}$ & $\begin{array}{l}20 \\
\min \end{array}$ & $\begin{array}{l}\text { HRR } \\
50 \% \\
-60 \%\end{array}$ \\
\hline \multirow{2}{*}{ Cool-down } & $\begin{array}{l}\text { Light } \\
\text { resistance } \\
\text { exercise }\end{array}$ & $\begin{array}{l}\text { Dumbbell } \\
\text { Ceraband } \\
(100-120) \\
\end{array}$ & $\begin{array}{c}5 \\
\min \end{array}$ & $\begin{array}{l}\text { HRR } \\
50 \% \\
-60 \% \\
\end{array}$ & $\begin{array}{c}5 \\
\min \end{array}$ & $\begin{array}{l}\text { HRR } \\
60 \% \\
-70 \% \\
\end{array}$ & $\begin{array}{c}5 \\
\min \end{array}$ & $\begin{array}{l}\text { HRR } \\
60 \% \\
-70 \% \\
\end{array}$ \\
\hline & $\begin{array}{l}\text { Supine } \\
\text { Stretch }\end{array}$ & $\begin{array}{c}\text { Relax } \\
\text { stretch } \\
(60-100)\end{array}$ & $\begin{array}{c}5 \\
\min \end{array}$ & $\begin{array}{l}\text { HRR } \\
40 \% \\
-50 \%\end{array}$ & $\begin{array}{c}5 \\
\min \end{array}$ & $\begin{array}{l}\text { HRR } \\
40 \% \\
-50 \%\end{array}$ & $\begin{array}{c}5 \\
\min \end{array}$ & $\begin{array}{l}\text { HRR } \\
40 \% \\
-50 \%\end{array}$ \\
\hline
\end{tabular}

HR: heart rate; HRR: heart rate reserve

\section{Outcome measures}

\section{Anthropometric measures}

Anthropometric data included body weight and height presented to the nearest $0.01 \mathrm{~kg}$ and $0.01 \mathrm{~cm}$, respectively. BMI was also calculated as body weight in kilograms divided by body height in meters squared $\left(\mathrm{kg} / \mathrm{m}^{2}\right)$.

\section{Blood analysis}

For determination of the factors related to glucose metabolism and liver enzymes, venous blood samples were obtained at pre- and post-training. Samplings at both pre- and post-training were performed at $10 \mathrm{am}$. Further, all participants were required to fast for 9 hours before extracting their blood sample. Approximately $10 \mathrm{~mL}$ of blood was extracted from the median antecubital vein and stored in an EDTA tube. The plasma was centrifuged for 15 minutes at $3,000 \mathrm{rpm}$ at $4^{\circ} \mathrm{C}$. Thereafter, the samples were stored frozen for subsequent analysis .

\section{Serum glucose level and IR score}

The serum glucose, insulin, glycated hemoglobin Alc (HbAlc), and 1,5-anhydroglucitol (1,5-AG) levels were measured via an absorptiometric analysis at $450 \mathrm{~nm}$ using an ELISA kit (MyBioSource, San Diego, CA, USA). To verify the changes in glucose metabolism, we additionally selected the HbA1c and 1,5-AG levels as glycemic markers. $\mathrm{HbAlc}$ is used as a marker to measure the mean glucose levels over a 3-month period, while 1,5-AG is a validated marker to evaluate short-term glycemic control $^{32}$. Further, the homeostatic model assessment of insulin resistance (HOMA-IR) score, which is an indicator of IR, was calculated using the following formula ${ }^{33}$.

HOMA-IR $=[\operatorname{Insulin}(\mu \mathrm{U} / \mathrm{ml}) \times \operatorname{Glucose}(\mathrm{mmol} / \mathrm{L})] / 22.5$

\section{Biomarkers of liver injury}

The levels of AST, ALT, and ALP, which are liver enzymes, and that of albumin, which is a protein, were measured using a biochemical analyzer (Hitachi, Tokyo, Japan). All of these are affected by liver damage. The AST, ALT, and ALP levels are elevated when the liver is injured, while lower than normal levels of albumin might indicate liver damage ${ }^{34}$. Moreover, the AST/ALT ratio is an important risk factor for predicting liver damage because the levels of AST increase more than those of ALT when hepatocellular death increases ${ }^{19}$.

\section{Statistical analysis}

All data were analyzed using the SPSS software version 25.0 (SPSS Inc., USA). Data were presented as means \pm standard deviations. To evaluate the changes in the factors related to glucose metabolism and liver function between pre- and post-training, the paired t-test was used. Statistical significance was set at $\mathrm{p}<0.05$.

\section{RESULTS}

\section{Serum glucose level}

Table 3 demonstrates the effects of the 8-week SEP on the factors related to the serum glucose level. There were significant decreases in all variables. The reductions in the serum glucose level (from $112.50 \pm 20.00$ to $94.50 \pm 9.43$ $\mathrm{mg} / \mathrm{dL}, \mathrm{p}<0.05$ ), HbA1c level (from $5.98 \pm 0.24$ to $5.53 \pm 0.09 \%, \mathrm{p}<0.05$ ), and 1,5-AG level (from $7.26 \pm 0.31$ to $6.57 \pm 0.19 \mu \mathrm{g} / \mathrm{mL}, \mathrm{p}<0.05$ ) were significant.

\section{Serum insulin level and HOMA-IR score}

Table 4 demonstrates the effects of the 8-week SEP on the serum insulin level and HOMA-IR score. There were significant reductions in both variables. The decreases 
in the insulin level (from $17.31 \pm 7.18$ to $8.07 \pm 3.94 \mu \mathrm{U} /$ $\mathrm{mL}, \mathrm{p}<0.01$ ) and HOMA-IR score (from 5.57 \pm 3.25 to $2.36 \pm 1.39, \mathrm{p}<0.05)$ were significant.

\section{Biomarkers of liver injury}

Table 5 demonstrates the effects of the 8-week SEP on the factors related to liver dysfunction. There were no significant decreases in the AST, ALT, and albumin levels and AST/ALT ratio. The increase in the ALP level (from $54.75 \pm 9.72$ to $55.63 \pm 10.01 \mathrm{U} / \mathrm{L})$ was significant $(\mathrm{p}<0.05)$.

Table 2. Anthropometric characteristics of the participants $(n=8)$

$\begin{array}{ccccc}\begin{array}{c}\text { Age } \\ \text { (year) }\end{array} & \begin{array}{c}\text { Height } \\ (\mathrm{cm})\end{array} & \begin{array}{c}\text { Weight } \\ (\mathrm{kg})\end{array} & \begin{array}{c}\mathrm{BMI} \\ \left(\mathrm{kg} / \mathrm{m}^{2}\right)\end{array} & \begin{array}{c}\text { Glucose level } \\ (\mathrm{mg} / \mathrm{dL})\end{array}\end{array}$

$66.60 \pm 2.87 \quad 155.7 \pm 3.77 \quad 63.37 \pm 4.20 \quad 26.29 \pm 1.82 \quad 112.50 \pm 20.00$

BMI: body mass index

Table 3. Glucose level before and after the training

\begin{tabular}{|cccc|}
\hline Clucose level & $\begin{array}{c}\text { HbA1c level } \\
(\mathrm{mg} / \mathrm{dL})\end{array}$ & $\begin{array}{c}1,5-\mathrm{AG} \text { level } \\
(\mu \mathrm{g} / \mathrm{mL})\end{array}$ \\
\hline Pre-training & $112.50 \pm 20.00$ & $5.98 \pm 0.24$ & $7.26 \pm 0.31$ \\
\hline Post-training & $94.50 \pm 9.43$ & $5.53 \pm 0.09$ & $6.57 \pm 0.19$ \\
\hline p-value & $<0.05$ & $<0.05$ & $<0.05$
\end{tabular}

HbA1c: glycated hemoglobin A1c; 1,5-AG: 1,5-anhydroglucitol

Table 4. Insulin resistance before and after the training

\begin{tabular}{ccc} 
& $\begin{array}{c}\text { Insulin level } \\
(\mu \mathrm{U} / \mathrm{mL})\end{array}$ & HOMA-IR score \\
\hline Pre-training & $17.31 \pm 7.18$ & $5.57 \pm 3.25$ \\
Post-training & $8.07 \pm 3.94$ & $2.36 \pm 1.39$ \\
p-value & $<0.01$ & $<0.05$
\end{tabular}

HOMA-IR: homeostatic model assessment of insulin resistance

Table 5. Biomarkers of liver injury before and after the training

$\begin{array}{cccccc}\begin{array}{c}\text { AST } \\ \text { level } \\ (\mathrm{U} / \mathrm{L})\end{array} & \begin{array}{c}\text { ALT } \\ \text { level } \\ (\mathrm{U} / \mathrm{L})\end{array} & \begin{array}{c}\text { AST } \\ \text { IALT } \\ \text { ratio }\end{array} & \begin{array}{c}\text { ALP } \\ \text { level } \\ (\mathrm{U} / \mathrm{L})\end{array} & \begin{array}{c}\text { Albumin } \\ \text { level } \\ (\mathbf{g} / \mathrm{dL})\end{array} \\ \begin{array}{c}\text { Pre- } \\ \text { training }\end{array} \\ \begin{array}{c}\text { Post- } \\ \text { training }\end{array} \\ \begin{array}{l}\text { 22.38 } 22.13 \pm 5.58 \\ \text { p-value }\end{array} & 0.516 .75 \pm 3.01 & 1.77 \pm 0.25 & 54.75 \pm 9.72 & 4.54 \pm 0.19 \\ \end{array}$

AST: aspartate aminotransferase; ALT: alanine aminotransferase; ALP: alkaline phosphatase

\section{DISCUSSION}

The aim of this study was to investigate whether regular aerobic exercise in elderly women with obesity and IFG has a beneficial effect on both glucose metabolism and liver enzymes. Based on the experimental results, all variables related to glucose metabolism significantly decreased. However, in contrast to our expectations, the increase in the ALP level was significant. In summary, there were no differences in the training effects on the liver enzymes, while all factors related to glucose metabolism improved after the 8-week SEP.

There have been consistent efforts to investigate the effects of exercise on the risk factors for liver diseases. However, to the best of our knowledge, only a few studies have investigated the effects of the SEP on both glucose metabolism and liver function. Most studies on the risk factors for liver diseases have focused on the different effects between aerobic exercise and resistance exercise or the effects of combinations of exercise and dietary interventions. These previous studies have shown that there is no significant difference in the effects on the risk factors for liver diseases between these two exercise regimens ${ }^{28,35-37}$. Further, other studies showed that the combination of exercise and diet can have positive effects on glucose metabolism ${ }^{38}$, liver damage ${ }^{39,40}$, or both ${ }^{41,42}$. However, these studies could not determine whether these beneficial effects were induced by exercise or diet. Considering that only a few studies have investigated the effect of aerobic exercise training on liver disease risk factors associated with glucose metabolism and liver function at the same time ${ }^{43,44}$, further experiments applying various types of exercise are required to determine the best type of exercise for the prevention of liver diseases.

In this study, there were significant differences in the factors associated with glucose metabolism between preand post-training. This indicates that the SEP can have a beneficial effect on glucose metabolism. The participants' glucose levels improved to a normal level (from $112.50 \pm 20.00$ to $94.50 \pm 9.43 \mathrm{mg} / \mathrm{dL}$ ). Improving glucose metabolism is one of the mechanisms suggested to prevent liver diseases. Lipolysis tends to increase in obesity; the release of excess free fatty acids (FFAs) into hepatocytes is augmented ${ }^{45}$. FFAs absorbed by hepatocytes are attached to coenzyme $\mathrm{A}(\mathrm{CoA})$ as fatty acyl-CoAs to shape hepatic triglycerides; this may induce a decrease in the insulin-induced glucose uptake ${ }^{46}$. However, fatty acylCoAs are not formed when the levels of FFAs are high; thus, this can stimulate intracellular inflammation and $I^{47}$. IR and hyperglycemia arising from this pathological state can promote liver apoptosis and hepatic steatosis ${ }^{24,45}$. Therefore, the results related to glucose metabolism may imply that the SEP may play a role in preventing obesity from progressing to liver diseases.

There were no significant differences in the factors related to liver injury between pre- and post-training. This indicates that the 8-week SEP had no beneficial effects on those variables. The reason why the factors, including the AST, ALT, and albumin levels and AST/ALT ratio, did not improve after the SEP might be that all participants already had normal levels before training. The participants had no NAFLD nor NASH; thus, their liver enzyme levels were normal even before the intervention. According to a meta-analysis of randomized trials, exercise cannot have an effect on liver enzymes, such as ALT, because the subjects already had normal levels ${ }^{48}$. Contrary to our results, exercise training reduced the ALT and AST levels in several trials of patients with liver diseases ${ }^{17,28,49}$. In contrast to our expectations, the ALP level increased after the 8-week SEP. There was a small increment in the ALP level, which was within the normal range (from 
$54.75 \pm 9.72$ to $55.63 \pm 10.01 \mathrm{U} / \mathrm{L})$. A previous study has reported a similar extent of increment in the ALP level after a 12-week endurance training (from $74.53 \pm 19.21$ to $75.47 \pm 19.26 \mathrm{U} / \mathrm{L})^{29}$. The serum ALP level also correlated positively with the visceral fat mass in middle-aged Koreans ${ }^{50}$. Thus, to determine the reason why the ALP levels increased after training, further studies measuring visceral fat between pre- and post-training should be conducted.

Our study has some limitations. First, our study was a pilot study including only one group; thus, we cannot ensure that the results were completely attributable to the exercise program. Therefore, further studies including a control group are required for verification of the interaction effects. Second, the sample size of the subjects was small. Further studies with larger sample sizes are necessary to augment the external validity of the present results. Lastly, the participants of our study were healthy individuals; thus, the application of our results to other medical conditions may be limited. Further studies on the effects of the SEP on various medical conditions are necessary to apply the SEP to various fields.

\section{CONCLUSION}

Regular aerobic exercises (i.e., SEP) may improve the glucose metabolism of elderly women with obesity and IFG. Considering the factors associated with glucose metabolism, the SEP may play an important role in preventing liver diseases.

\section{ACKNOWLEDGMENTS}

This work was supported by the Ministry of Education of the Republic of Korea and the National Research Foundation of Korea (NRF-2017S1A5A2A01026434). The present research has been conducted by the Research Grant of Kwangwoon University in 2017.

\section{REFERENCES}

1. World Health Organization. Obesity and overweight. WHO. 2018.

2. Finucane MM, Stevens GA, Cowan MJ, Danaei G, Lin JK, Paciorek CJ, Singh GM, Gutierrez HR, Lu Y, Bahalim AN, Farzadfar F, Riley LM, Ezzati M. National, regional, and global trends in body-mass index since 1980: systematic analysis of health examination surveys and epidemiological studies with 960 country-years and 91 million participants. Lancet. 2011;377:557-67.

3. Garawi F, Devries K, Thorogood N, Uauy R. Global differences between women and men in the prevalence of obesity: is there an association with gender inequality? Eur J Clin Nutr. 2014;68:1101-6.

4. Hales CM, Fryar CD, Carroll MD, Freedman DS, Oqden CL. Trends in obesity and severe obesity prevalence in US youth and adults by sex and age, 2007-2008 to 2015-2016. JAMA. 2018;319:1723-5.

5. Kanter R, Caballero B. Global gender disparities in obesity: a review. Adv Nutr. 2012;3:491-8.

6. Oh C, Jho S, No JK, Kim HS. Body composition changes were related to nutrient intakes in elderly men but elderly women had a higher prevalence of sarcopenic obesity in a population of Korean adults. Nutr Res. 2015;35:1-6.

7. Karvonen-Gutierrez C, Kim C. Association of mid-life changes in body size, body composition and obesity status with the menopausal transition. Healthcare (Basel). 2016;4:42.

8. Amarapurkar D, Kamani P, Patel N, Gupte P, Kumar P, Agal S, Baijal R, Lala S, Chaudhary D, Deshpande A. Prevalence of non-alcoholic fatty liver disease: population based study. Ann Hepatol. 2007;6:161-3.

9. Milić $S$, Lulić $D$, Štimac D. Non-alcoholic fatty liver disease and obesity: biochemical, metabolic and clinical presentations. World J Gastroenterol. 2014;20:9330-7.

10. Patell R, Dosi R, Joshi H, Sheth $S$, Shah P, Jasdanwala S. Non-alcoholic fatty liver disease (NAFLD) in obesity. J Clin Diagn Res. 2014;8:62-6.

11. Williams CD, Stengel J, Asike MI, Torres DM, Shaw J, Contreras M, Landt CL, Harrison SA. Prevalence of nonalcoholic fatty liver disease and nonalcoholic steatohepatitis among a largely middle-aged population utilizing ultrasound and liver biopsy: a prospective study. Gastroenterology. 2011;140:12431.

12. Feng RN, Du SS, Wang C, Li YC, Liu LY, Guo FC, Sun CH. Lean-non-alcoholic fatty liver disease increases risk for metabolic disorders in a normal weight Chinese population. World J Gastroenterol. 2014;20:17932-40.

13. Armstrong MJ, Houlihan DD, Bentham L, Shaw JC, Cramb R, Olliff S, Gill PS, Neuberger JM, Lilford RJ, Newsome $\mathrm{PN}$. Presence and severity of non-alcoholic fatty liver disease in a large prospective primary care cohort. $J$ Hepatol. 2012;56:234-40.

14. van der Windt DJ, Sud V, Zhang H, Tsung A, Huang $H$. The effects of physical exercise on fatty liver disease. Gene Expr. 2018;18:89-101.

15. Michelotti GA, Machado MV, Diehl AM. NAFLD, NASH and liver cancer. Nat Rev Gastroenterol Hepatol. 2013;10:656-65.

16. Wong RJ, Aguilar M, Cheung R, Perumpail RB, Harrison SA, Younossi ZM, Ahmed A. Nonalcoholic steatohepatitis is the second leading etiology of liver disease among adults awaiting liver transplantation in the United States. Gastroenterology. 2015;148:547-55.

17. St George A, Bauman A, Johnston A, Farrell G, Chey T, George J. Independent effects of physical activity in patients with nonalcoholic fatty liver disease. Hepatology. 2009;50:6876.

18. Contreras-Zentella ML, Hernández-Muñoz R. Is liver enzyme release really associated with cell necrosis induced by oxidant stress? Oxid Med Cell Longev. 2016;2016:3529149.

19. Botros M, Sikaris KA. The de ritis ratio: the test of time. Clin Biochem Rev. 2013;34:117-30.

20. Bray GA. Medical consequences of obesity. J Clin Endocrinol Metab. 2004;89:2583-9.

21. Parati G, Lombardi C, Narkiewicz K. Sleep apnea: epidemiol- 
ogy, pathophysiology, and relation to cardiovascular risk. Am J Physiol Regul Integr Comp Physiol. 2007;293:R1671-83.

22. Bechmann LP, Hannivoort RA, Gerken G, Hotamisligil GS, Trauner M, Canbay A. The interaction of hepatic lipid and glucose metabolism in liver diseases. J Hepatol. 2012;56:95264.

23. Kistler KD, Brunt EM, Clark JM, Diehl AM, Sallis JF, Schwimmer JB, NASH CRN Research Group. Physical activity recommendations, exercise intensity, and histological severity of nonalcoholic fatty liver disease. Am J Gastroenterol. 2011;106:460-8.

24. García-Monzón C, Lo lacono O, Mayoral R, González-Rodríguez A, Miquilena-Colina ME, Lozano-Rodríguez T, García-Pozo L, Vargas-Castrillón J, Casado M, Boscá L, Valverde AM, Martín-Sanz P. Hepatic insulin resistance is associated with increased apoptosis and fibrogenesis in nonalcoholic steatohepatitis and chronic hepatitis C. J Hepatol. 2011;54:142-52.

25. Kantartzis K, Machann J, Schick F, Fritsche A, Häring HU, Stefan N. The impact of liver fat vs visceral fat in determining categories of prediabetes. Diabetologia. 2010;53:882-9.

26. Yin X, Zheng F, Pan Q, Zhang S, Yu D, Xu Z, Li H. Glucose fluctuation increased hepatocyte apoptosis under lipotoxicity and the involvement of mitochondrial permeability transition opening. J Mol Endocrinol. 2015;55:169-81.

27. American Gastroenterological Association. American Gastroenterological Association medical position statement: nonalcoholic fatty liver disease. Gastroenterology. 2002;123:17024.

28. Shamsoddini A, Sobhani V, Ghamar Chehreh ME, Alavian $\mathrm{SM}$, Zaree A. Effect of aerobic and resistance exercise training on liver enzymes and hepatic fat in iranian men with nonalcoholic fatty liver disease. Hepat Mon. 2015;15:e31434.

29. Skrypnik D, Ratajczak M, Karolkiewicz J, Mądry E, Pupek-Musialik D, Hansdorfer-Korzon R, Walkowiak J, Jakubowski $H$, Bogdański P. Effects of endurance and endurance-strength exercise on biochemical parameters of liver function in women with abdominal obesity. Biomed Pharmacother. 2016;80:1-7.

30. American Diabetes Association. 2. Classification and diagnosis of diabetes: standards of medical care in diabetes-2018. Diabetes Care. 2018;41:S13-27.

31. World Health Organization. Regional Office for the Western Pacific. The Asian-Pacific perspective: redefining obesity and its treatment. Sydney: Health Communications Australia. 2000.p18.

32. Dungan KM. 1,5-anhydroglucitol (GlycoMark) as a marker of short-term glycemic control and glycemic excursions. Expert Rev Mol Diagn. 2008;8:9-19.

33. Matthews DR, Hosker JP, Rudenski AS, Naylor BA, Treacher DF, Turner RC. Homeostasis model assessment: insulin resistance and beta-cell function from fasting plasma glucose and insulin concentrations in man. Diabetologia. 1985;28:4129.

34. Woreta TA, Alqahtani SA. Evaluation of abnormal liver tests. Med Clin North Am. 2014;98:1-16.

35. Bacchi E, Negri C, Targher G, Faccioli N, Lanza M, Zoppini G, Zanolin E, Schena F, Bonora E, Moghetti P. Both resistance training and aerobic training reduce hepatic fat content in type 2 diabetic subjects with nonalcoholic fatty liver disease (the RAED2 Randomized Trial). Hepatology. 2013;58:128795.

36. Balducci S, Cardelli P, Pugliese L, D'Errico V, Haxhi J, Alessi E, lacobini C, Menini S, Bollanti L, Conti FG, Nicolucci A, Pugliese G, Italian Diabetes Exercise Study (IDES) Investigators. Volume-dependent effect of supervised exercise training on fatty liver and visceral adiposity index in subjects with type 2 diabetes The Italian Diabetes Exercise Study (IDES). Diabetes Res Clin Pract. 2015;109:355-63.

37. Lee S, Bacha F, Hannon T, Kuk JL, Boesch C, Arslanian S. Effects of aerobic versus resistance exercise without caloric restriction on abdominal fat, intrahepatic lipid, and insulin sensitivity in obese adolescent boys: a randomized, controlled trial. Diabetes. 2012;61:2787-95.

38. Straznicky NE, Lambert EA, Grima MT, Eikelis N, Nestel PJ, Dawood T, Schlaich MP, Masuo K, Chopra R, Sari Cl, Dixon JB, Tilbrook AJ, Lambert GW. The effects of dietary weight loss with or without exercise training on liver enzymes in obese metabolic syndrome subjects. Diabetes Obes Metab. 2012;14:139-48.

39. Larson-Meyer DE, Newcomer BR, Heilbronn LK, Volaufova J, Smith SR, Alfonso AJ, Lefevre M, Rood JC, Williamson DA, Ravussin E, Pennington CALERIE Team. Effect of 6-month calorie restriction and exercise on serum and liver lipids and markers of liver function. Obesity (Silver Spring). 2008;16:1355-62.

40. Promrat K, Kleiner DE, Niemeier HM, Jackvony E, Kearns M, Wands JR, Fava JL, Wing RR. Randomized controlled trial testing the effects of weight loss on nonalcoholic steatohepatitis. Hepatology. 2010;51:121-9.

41. Tamura Y, Tanaka Y, Sato F, Choi JB, Watada H, Niwa M, Kinoshita J, Ooka A, Kumashiro N, Igarashi Y, Kyogoku S, Maehara T, Kawasumi M, Hirose T, Kawamori R. Effects of diet and exercise on muscle and liver intracellular lipid contents and insulin sensitivity in type 2 diabetic patients. J Clin Endocrinol Metab. 2005;90:3191-6.

42. Shah K, Stufflebam A, Hilton TN, Sinacore DR, Klein S, Villareal DT. Diet and exercise interventions reduce intrahepatic fat content and improve insulin sensitivity in obese older adults. Obesity (Silver Spring). 2009;17:2162-8.

43. Cuthbertson DJ, Shojaee-Moradie F, Sprung VS, Jones H, Pugh CJ, Richardson P, Kemp GJ, Barrett M, Jackson NC, Thomas EL, Bell JD, Umpleby AM. Dissociation between exercise-induced reduction in liver fat and changes in hepatic and peripheral glucose homoeostasis in obese patients with non-alcoholic fatty liver disease. Clin Sci (Lond). 2016;130:93-104.

44. Damor K, Mittal K, Bhalla AS, Sood R, Pandey RM, Guleria R, Luthra K, Vikram NK. Effect of progressive resistance exercise training on hepatic fat in Asian Indians with non-alcoholic fatty liver disease. Br J Med Med Res. 2014;4:114-24.

45. Stefan N, Kantartzis K, Häring HU. Causes and metabolic consequences of fatty liver. Endocr Rev. 2008;29:939-60.

46. Wellen KE, Hotamisligil GS. Inflammation, stress, and diabetes. J Clin Invest. 2005;115:1111-9.

47. Shi H, Kokoeva MV, Inouye K, Tzameli I, Yin H, Flier JS. 
TLR4 links innate immunity and fatty acid-induced insulin resistance. J Clin Invest. 2006;116:3015-25.

48. Keating SE, Hackett DA, George J, Johnson NA. Exercise and non-alcoholic fatty liver disease: a systematic review and meta-analysis. J Hepatol. 2012;57:157-66.

49. Sreenivasa Baba C, Alexander G, Kalyani B, Pandey R, Rastogi S, Pandey A, Choudhuri G. Effect of exercise and dietary modification on serum aminotransferase levels in patients with nonalcoholic steatohepatitis. J Gastroenterol Hepatol. 2006;21:191-8.

50. Kim MK, Baek KH, Kang MI, Park SE, Rhee EJ, Park CY, Lee WY, Oh KW. Serum alkaline phosphatase, body composition, and risk of metabolic syndrome in middle-aged Korean. Endocr J. 2013;60:321-8. 